\title{
Pre- and post-puberty physiological plasma oxytocin concentrations in male domestic cats (Felis silvestris catus) ${ }^{1}$
}

\author{
José O.T. Souza ${ }^{2}$, Artur Andriolo² ${ }^{2}$ Celso R. Franci ${ }^{3}$ and Gelson Genaro ${ }^{4 *}$
}

\begin{abstract}
Souza J.O.T., Andriolo A., Franci C.R. \& Genaro G. 2012. Pre- and post-puberty physiological plasma oxytocin concentrations in male domestic cats (Felis silvestris catus). Pesquisa Veterinária Brasileira 32(11):1196-1198. Programa de Pós-Graduação em Psicobiologia, Faculdade de Filosofia Ciências e Letras de Ribeirão Preto, Universidade de São Paulo, Cx. Postal 390, Ribeirão Preto, SP 14001-970, Brazil. E-mail: gelsongenaro@hotmail.com

The hormone oxytocin is released by the neuropituitary gland through stimulation of the neurons of the supraoptic and paraventricular nuclei of the hypothalamus. In order to determine the physiological concentrations of this hormone in domestic cats, blood samples were collected from 15 male animals (Felis silvestris catus) during the pre- and post-puberty periods (at four and eight months of age, respectively). Oxytocin determination was accomplished by radioimmunoassay. The average oxytocin concentrations measured in the preand post-puberty periods were $2.54 \pm 0.24(\mu \mathrm{g} / \mathrm{dL})$ and $2.53 \pm 0.28(\mu \mathrm{g} / \mathrm{dL})$, respectively, and there were no statistical differences between these measurements. Because there are few literature on the analysis of this hormone, especially in the case of male Felis silvestris catus, more studies on the influence of oxytocin on the physiology and reproduction of this species should be conducted under maintenance and situations of stress (such as transportation), and other routine events.
\end{abstract}

INDEX TERMS: Domestic cats, Felis silvestris catus, oxytocin, male.

RESUMO.- [Concentrações fisiológicas plasmáticas de ocitocina pré e pós-puberal em gatos machos (Felis silvestris catus).] A ocitocina é um hormônio secretado pela neurohipófise através da estimulação dos neurônios dos núcleos supraópticos e paraventriculares do hipotálamo. Com o intuito de determinar as concentrações fisiológicas de ocitocina em gatos domésticos foram coletadas amostras de sangue de 15 animais (Felis silvestris catus) machos, nos períodos pré e pós puberdade (quarto e oitavo mês de vida), sendo utilizada a técnica de radioimunoensaio para tal determinação. Na primeira dosagem a concentração média foi de $2,54 \pm 0,24(\mu \mathrm{g} / \mathrm{dL})$, e na segunda $2,53 \pm 0,28(\mu \mathrm{g} /$

\footnotetext{
${ }^{1}$ Received on April 2, 2012.

Accepted for publication on September 6, 2012.

${ }^{2}$ Programa de Pós-Graduação em Comportamento e Biologia Animal, Departamento de Zoologia, Universidade Federal de Juiz de Fora (UFJF), Instituto de Ciências Biológicas (ICB), Campus Universitário, Martelos, Juiz de Fora, MG 36036-900, Brazil.

${ }^{3}$ Departamento de Fisiologia, Faculdade de Medicina de Ribeirão Preto, Universidade de São Paulo (USP), Av. Bandeirantes 3900, Bairro Monte Alegre, Ribeirão Preto, SP 14049-900, Brazil.

${ }^{4}$ Programa de Pós-Graduação em Psicobiologia, Faculdade de Filosofia Ciências e Letras de Ribeirão Preto (FFCLRP-USP), Ribeirão Preto, SP 14049-900. *Corresponding author: gelsongenaro@hotmail.com
}

dL), não sendo encontrada diferenças significativas entre as médias analisadas. Devido a escassez de trabalhos analisando este hormônio, especialmente para machos desta espécie, sugere-se mais estudos abordando a influência deste hormônio na fisiologia e reprodução destes animais, tanto em condições de manutenção, condições de estresse, como no transporte e outras situações de rotina na vida destes animais.

TERMOS DE INDEXAÇÃO: Gato doméstico, Felis silvestris catus, ocitocina, macho.

\section{INTRODUCTION}

The nanopeptide oxytocin is a neuropituitary hormone synthesized in the supraoptic and paraventricular neurons of the hypothalamus. Stimulation of these neurons triggers oxytocin relase from the neuropituitary gland into the bloodstream (Chriguer et al. 2001, Gimpl \& Fahrenholz 2001, Klenerova et al. 2009). This hormone has an extremely important influence on animal physiology. In the case of female animals, one of its major actions is to cause contraction of the milk ducts system, thereby helping to expel the milk. Another action is to promote contractions of the uterus during labor and mating (Cooke et al. 1998, Kotwi- 
ca et al. 1999). However, there are few studies on the role of oxytocin in male animals, but this hormone is known to aid sperm transport during mating (Moos et al. 1989, Elier 2006).

Apart from its role in hydroeletrolytic homeostasis, oxytocin also exhibits natriuretic and caliuretic effects. As in the case of vasopressin, this hormone is secreted in response to hyperosmolality and hypovolemia (Verbalis et al. 1991, Chriguer et al. 2001, Lucca Junior \& Franci 2004, Antunes-Rodrigues et al. 2005). Like other hormones described for male domestic cats in the literature (Windle et al. 2006, Uchoa et al. 2009), oxytocin is also involved in stress events (Neto et al. 2004, Genaro et al. 2007, Genaro \& Franci 2010).

Because there are few reports on the physiological concentrations of oxytocin in domestic cats, especially males, this work aimed to determine the normal blood oxytocin levels in male Felis silvestris catus aged four and eight months.

\section{MATERIALS AND METHODS}

Fifteen clinically healthy male cats (Felis silvestris catus) of undefined breed were used in this study. The animals were housed in catteries measuring $4 \mathrm{~m}^{2}$, located in the Laboratório Avançado de Zoologia do Programa de Pós-Graduação em Ciências Biológicas, Universidade Federal de Juiz de Fora, MG, Brazil (Laboratory of Advanced Zoology of the Postgraduate Program in Biological Sciences, Federal University of Juiz de Fora, Minas Gerais, Brazil). An area of $0.8 \mathrm{~m}^{2}$ was available for each animal, a value above the dimensions recommended by Rochlitz (1999).

The animals were vermifuged (Endal Gatos ${ }^{\circledR}$, Schering Plough) and vaccinated (Feline- $4^{\circledR}$ and Rabisin ${ }^{\circledR}$, Merial) against the main viroses and verminoses. They were fed on commercial cat food (Frisckies ${ }^{\circledR}$, Purina) using the amount recommended by the manufacturer, and water was available ad libitum. Prior to the start of the experiment, the animals were left to adapt to the cattery and food for 60 days.

For determination of oxytocin levels, 1-mL blood samples were collected from each animal at the fourth (sample 1) and eighth (sample 2) month of age by external jugular vein puncture. After centrifugation, the samples were stored at $-80^{\circ} \mathrm{C}$ and later analyzed by radioimmunoassay (RIA) at Laboratório de Neuroendocrinologia do Campus de Ribeirão Preto, Universidade de São Paulo (Laboratory of Neuroendocrinology, Ribeirão Preto Campus, University of São Paulo).

Oxytocin plasma levels were determined by RIA using kits from the National Institute of Diabetes and Digestive and Kidney Diseases (NIDDK/NIH-USA). All results were expressed in terms of the $\mathrm{NIH}-\mathrm{RP}_{2}$ reference standards. The lower limits of detection were $0.04 \mathrm{pg} / \mathrm{mL}$. The intra-assay coefficients of variation were $4 \%$.

The Wilcoxon test was employed for analysis of values obtained between two collections. The $t$ was used for comparison between individuals in the collections (BioEstat 5.0).

The present project was submitted to the appreciation of the Comitê de Ética em Experimentação Animal (CEEA, Ethics Committee on Animal Research) of the Pro-Rectory of Research of Universidade Federal de Juiz de Fora (UFJF, Federal University of Juiz de Fora), under protocol number 025/2005-CEA, approved on May 24, 2008.

\section{RESULTS AND DISCUSSION}

Our results show that the mean oxytocin plasma concentrations in the first and second samples were $2.47 \pm 0.24$
(pmol/L) and $2.46 \pm 0.28(\mathrm{pmol} / \mathrm{L})$, respectively. There were no statistical differences between the average values obtained for samples 1 and 2 ( $\mathrm{t}=0.066$; g.l. $=1$; $\mathrm{p}=0.957$; see Table 1).

Table 1. Mean and standard mean deviation $(\mu \mathrm{g} / \mathrm{dL})$ of plasma oxytocin levels in non-castrated male domestic cats (Felis silvestris catus) of undefined breed measured by radioimmunoassay. Samples collected at 4 and 8 months of age (pre- and post-puberty periods)

\begin{tabular}{ccc}
\hline Animal & 4 months & 8 months \\
\hline 1 & $1.70(0.30)$ & $4.20(0.00)$ \\
2 & $1.45(0.05)$ & $1.25(0.05)$ \\
3 & $3.80(1.20)$ & $3.05(2.25)$ \\
4 & $2.00(0.00)$ & $1.70(0.50)$ \\
5 & $2.20(0.00)$ & $3.60(0.00)$ \\
6 & - & $4.70(0.00)$ \\
7 & $2.60(0.60)$ & $2.50(0.00)$ \\
8 & $3.80(0.00)$ & $2.60(1.40)$ \\
9 & $2.40(0.00)$ & $1.45(0.35)$ \\
10 & $3.60(1.40)$ & $2.30(0.10)$ \\
11 & $1.50(0.50)$ & $3.10(1.70)$ \\
12 & $2.00(0.00)$ & $1.60(0.00)$ \\
13 & $1.80(1.00)$ & $1.10(0.00)$ \\
14 & $3.20(0.00)$ & $2.55(1.55)$ \\
15 & $3.55(2.55)$ & $2.20(0.00)$ \\
Mean & $2.54(0.24)$ & $2.53(0.28)$
\end{tabular}

Compared to rats (Rattus norvergicus), oxytocin plasma levels found in cats are lower, since the concentration for rodents is reported to lie between $7.7 \pm 1.1(\mathrm{pmol} / \mathrm{L})$ (Carter and Lightman 1987) and 19.5 \pm 4.5 (pmol/L) (Higuchi et al. 1985). Fieni et al. (2006) have described oxytocin plasma levels of $37.7 \pm 9.5(\mathrm{pmol} / \mathrm{L})$ in pregnant female cats, which is well above those encountered in males, thereby highlighting the importance of this hormone during pregnancy, labor, and lactation (Cooke et al. 1998; Kotwica et al. 1999).

Analysis of the oxytocin values obtained for each of the animals from samples $1(\mathrm{t}=0.012$; g.l $=14 ; \mathrm{p}=0.990)$ and $2(\mathrm{t}=0.024 ; \mathrm{g} . \mathrm{l} .=14 ; \mathrm{p}=0.981)$ does not reveal any significant differences, either $(\mathrm{Z}=-0.340 ; \mathrm{p}=0.733)$. Therefore, no variation in the oxytocin plasma levels were registered between the $4^{\text {th }}$ and $8^{\text {th }}$ month of age, a period when the domestic cat goes from the juvenile to the adult phase of the life cycle, the latter of which marks the beginning of the reproductive period.

\section{CONCLUSION}

Results from the present study demonstrate that oxytocin plasma levels in male cats aged 4 and 8 months are not significantly different, and that normal values of this hormone in males are lower compared with those detected in pregnant females. Therefore, during this stage of the life cycle of this species and gender, there is only a slight fluctuation in the concentration of this hormone under the conditions proposed here.

Because of the very few papers on oxytocin plasma levels in male Felis silvestris catus, more studies should be undertaken to assess the influence of this hormone on the physiology, development and reproduction of these ani- 
mals, especially under maintenance conditions (for instance, transportation and other routine events involved in the routine conduction and handling of these animals), once this hormone is also related to situations of stress.

\section{REFERENCES}

Antunes-Rodrigues J., Picanço-Diniz D.L.W., Valença M.M. \& McCann S.M. 2005. Neuroendocrinologia Básica e Aplicada. Editora Guanabara Koogan, Rio de Janeiro, p.81-115.

Carter D.A. \& Lightman S.L. 1987. Oxytocin responses to stress in lactating and hyperprolactinaemic rats. Neuroendocrinol. 46: 532-537.

Chriger R.S., Rocha M.J.A., Antunes-Rodrigues J. \& Franci C.R. 2001. Hypothalamic atrial natriuretic peptide and secretion of oxytocin. Brain Res. 889: 239-242.

Cooke R.G., Ahmad N. \& Nicholson T. 1998. Suppression of ovarian oxytocin secretion after intra-luteal administration of the arachidonate 5-lipoxygenase inhibitor BWA4C in the ewe. Res. Vet. Sci. 64:263-264.

Elier H. 2006. Glândulas endócrinas, p.571-622. In: M.J. Swenson \& W.O. Reece (Eds), Dukes, Fisiologia dos Animais Domésticos. 12ª ed. Editora Guanabara Koogan, Rio de Janeiro.

Fieni F., Marthal J., Marnet P.G., Siliart B. \& Guittot F. 2006. Clinical, biological and hormonal study of mind-pregnancy termination in cats with aglepristone. Theriogenol. 66:1721-1728.

Genaro G. \& Franci C.R. 2010. Cortisol influence on testicular testosterone secretion in domestic cat: An in vitro study. Pesq. Vet. Bras. 30:887-890.

Genaro G., Moraes W., Silva J.C.R., Adania C.H. \& Franci C.R. 2007. Plasma hormones in neotropical and domestic cats undergoing routine manipulations. Res. Vet. Sci. 82:263-270.

Gimpl G. \& Fahrenholz F. 2001. The oxytocin receptor system: structure, function and regulation. Physiol. Rev. 2:629-683.
Higuchi T., Honda K., Fukuoka T., Negoro H. \& Wakabayashi K. 1985. Release of oxytocin during suckling and parturition in the rat. J. Endocrinol. 105:339-346.

Klenerova V., Krejci I., Sida P., Hlinak Z. \& Hynie S. 2009. Modulatory effects of oxytocin and carbetocin on stress-induced changes in rat behavior in the open-field. J. Physiol. Pharmacol. 60:57-62.

Kotwica J., Skarzynski G., Miszkiel G., Melin P. \& Okuda K. 1999. Oxytocin modulates the pulsatile secretion of prostaglandin F2 $\alpha$ in initiated luteolysis in cattle. Res. Vet. Sci. 66:1-5.

Lucca Júnior W. \& Franci C.R. 2004. Angiotensinergic pathway through the median preoptic nucleus in the control of oxytocin secretion and water and sodium intake. Brain Res. 1014:236-243.

Moos F., Poulain D.A., Rodriguez P., Guerné Y., Vincent J.D. \& Richard P.H. 1989. Release of oxytocin within the supraoptic nucleus during the milk ejection reflex in rats. Exp. Brain Res. 76:593-602.

Neto J.C.L., Barbosa J.C., Rosa e Silva A.A.M. \& Genaro G. 2004. Effects of surgical stress on the secretion of luteinizing hormone, testosterone and cortisol in the domestic cat (Felis catus). Ciênc. Anim. Bras. 5:211-214.

Rochlitz I. 1999. Recommendations for the housing of cats in the home, in catteries and animal shelters, in laboratories and in veterinary surgeries. J. Fel. Med. Surg. 1:181-191.

Uchoa E.T., Silva L.E.C.M., Castro M., Antunes-Rodrigues J. \& Elias L.L. 2009. Hypothalamic oxytocin neurons modulate hypophagic effect induced by adrenalextomy. Horm. Behav. 56:532-538.

Verbalis J.G., Mangione M.P. \& Stricker E.M. 1991. Oxytocin produces natriuresis in rats at physiological plasma concentrations. Endocrinol. 128:1317-1322.

Windle R.J., Gamble L.E., Kershaw Y.M., Wood S.A., Lightman S.L. \& Ingram C.D. 2006. Gonadal steroid modulation of stress-induced hypothalamo-pituitary-adrenal activity and anxiety behavior: Role of central oxytocin. Endocrinol. 147:2423-2431. 